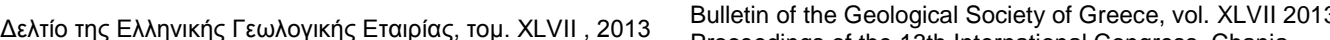

\title{
A RE-ASSESSESMENT OF THE SHALLOW PALEOMAGNETIC INCLINATIONS OF THE WESTERN CYCLADES, GREECE
}

\author{
Bradley K.E. ${ }^{1,3}$, Vassilakis E. ${ }^{2}$, Weiss B.P. ${ }^{3}$ and Royden L.H. ${ }^{3}$ \\ 1,3 Nanyang Technological University, Earth Observatory of Singapore, kbradley@ntu.edu.sg \\ ${ }^{2}$ National and Kapodistrian University of Athens, Faculty of Geology and Geoenvironment, \\ Department of Dynamic, Tectonic \& Applied Geology, evasilak@geol.uoa.gr \\ ${ }^{3}$ Massachusetts Institute of Technology, Department of Earth, Atmospheric, and Planetary \\ Science,bpweiss@mit.edu,lhroyden@mit.edu
}

\begin{abstract}
Consistently shallow paleomagnetic inclinations measured in Early to Middle Miocene lacustrine and dacitic volcanic rocks of the Kymi-Aliveri basin have been cited as evidence for an anomalous geomagnetic field geometry or northward drift of the Aegean Sea region. We present new paleomagnetic data from the lacustrine beds that are instead not anomalously shallow and consistent with deposition near their present-day latitude as predicted by global apparent polar wander paths. Anomalously shallow inclinations and easterly declinations reported from the Oxylithos volcanics are an artifact of an inappropriate tilt correction. The excessively shallow paleomagnetic inclinations reported from the deformed Middle Miocene plutons on Mykonos and Naxos are consistent with reorientation of an original thermoremanent magnetization acquired during cooling below $580^{\circ} \mathrm{C}$ by subsequent ductile strain at temperatures of $400-500^{\circ} \mathrm{C}$. Magnetization overprints observed in these rocks may reflect the acquisition of a stable chemical remanent magnetization lying parallel to the transposed high-temperature magnetization as the result of low-temperature $\left(<350^{\circ} \mathrm{C}\right)$ maghemitization. We therefore find no convincing evidence for an anomalous Middle Miocene field geometry, northward drift of the Aegean, or back-tilting of the low-angle normal faults that constitute the North Cycladic Detachment System.

Key words: Tectonics, paleomagnetism, detachment, paleolatitude, Kymi-Aliveri basin.
\end{abstract}

\section{Пєрí $\eta \psi \eta$}

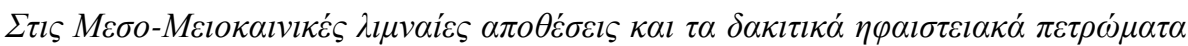

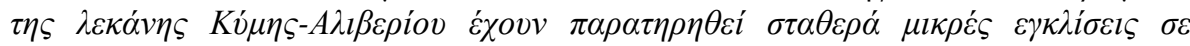

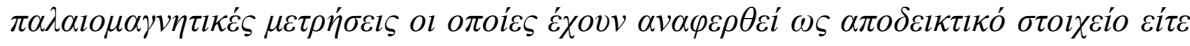

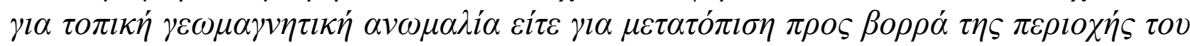

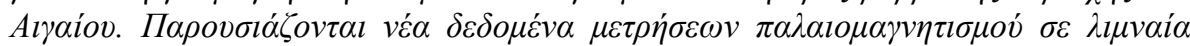

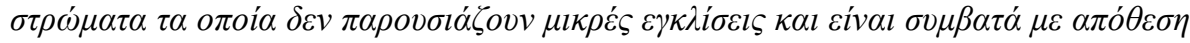

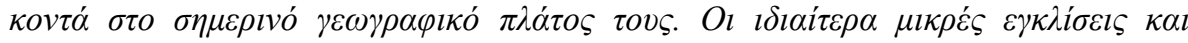

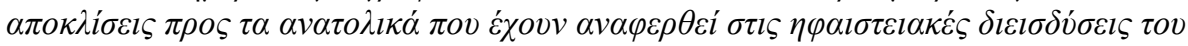

XLVII. No $2-498$ 


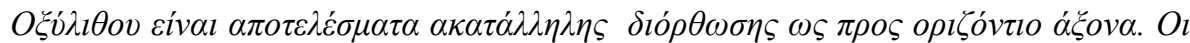

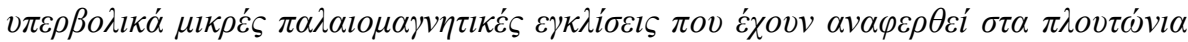

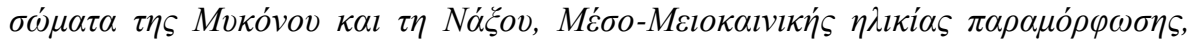

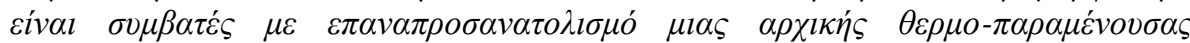

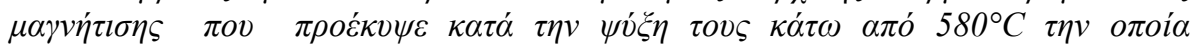
$\alpha \kappa o \lambda о v ́ \theta \eta \sigma \varepsilon \quad l \xi \omega \delta о \varepsilon \lambda \alpha \sigma \tau \imath \kappa \dot{~} \quad \pi \alpha \rho \alpha \mu o ́ \rho \varphi \omega \sigma \eta \quad \sigma \varepsilon \quad \theta \varepsilon \rho \mu о \kappa \rho \alpha \sigma i \varepsilon \varsigma \quad 400-500^{\circ} \mathrm{C}$. $\triangle \varepsilon v \tau \varepsilon \rho \varepsilon \dot{o v \sigma \varepsilon \varsigma} \quad \mu \alpha \gamma v \eta \tau i ́ \sigma \varepsilon l \varsigma \quad \pi o v \quad \pi \alpha \rho \alpha \tau \eta \dot{\eta} \theta \eta \kappa \alpha v \quad \sigma \tau \alpha \quad \pi \varepsilon \tau \rho \omega ́ \mu \alpha \tau \alpha \quad \alpha v \tau \dot{~}$

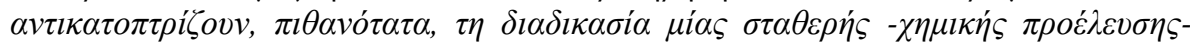

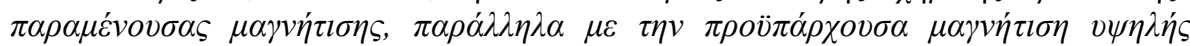

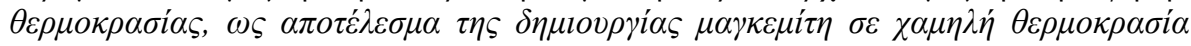

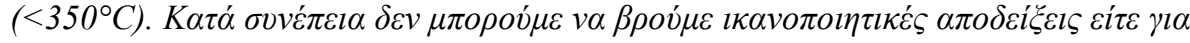

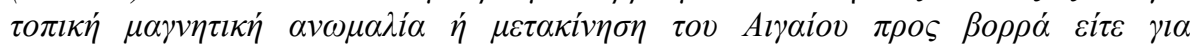

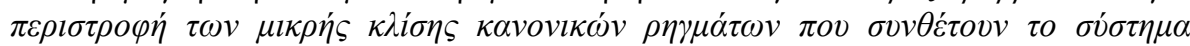

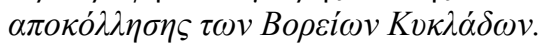

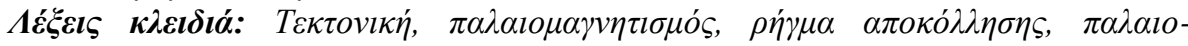

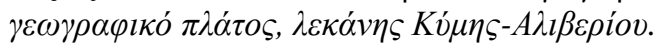
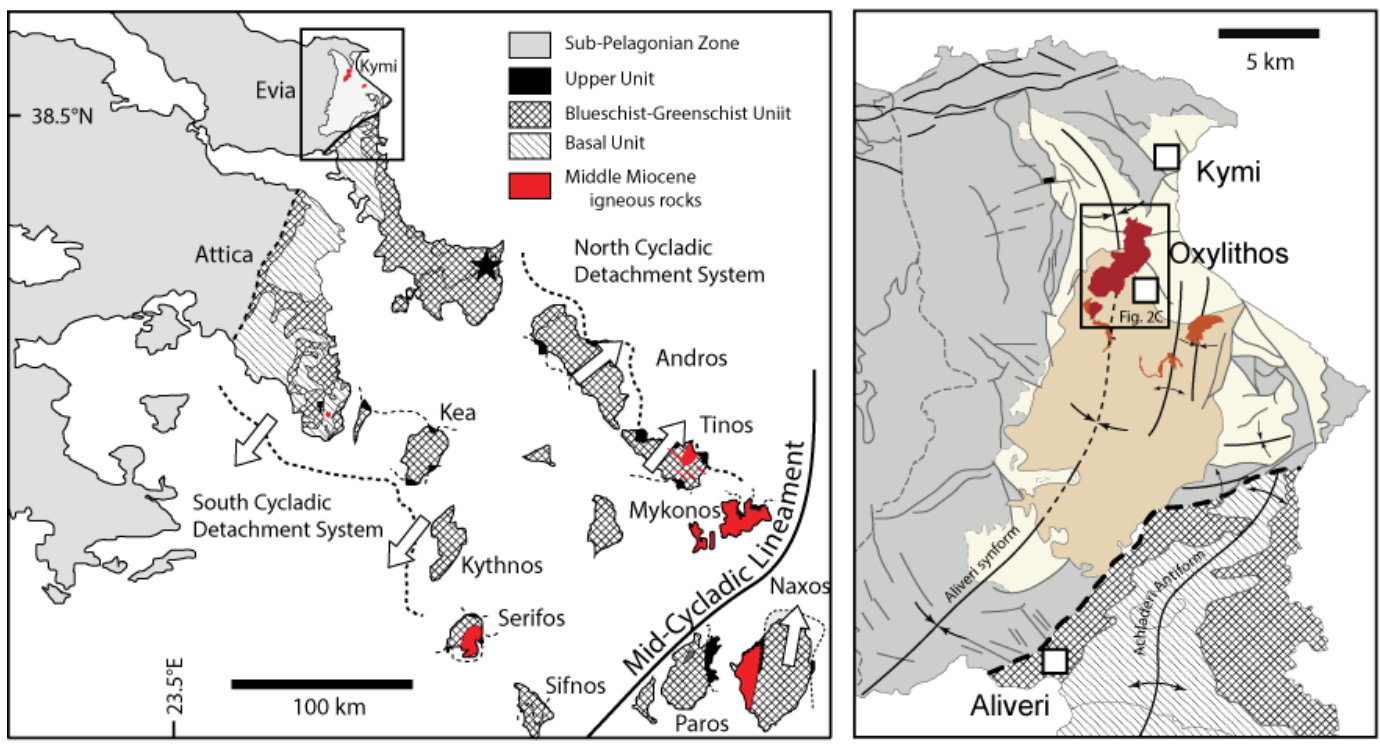

Figure 1 -Generalized geological maps of the western Cycladic archipelago and the KymiAliveri basin. Box in left panel shows location of the Kymi-Aliveri basin, shown in detail in the right panel. Location of map in Fig. $2 \mathrm{C}$ is given by box in right panel. Star: site for which we have calculated an expected Miocene field geometry.

\section{Introduction}

Paleomagnetic data have formed the basis for a number of regional paleogeographic reconstructions of the greater Aegean Sea region (e.g., Kissel and Laj, 1988; van Hinsbergen et al., 2005; Bradley et al., 2013). The utility of this method in resolving regional rotations, translations, and tilting of crustal blocks is largely dependent on the validity of the geocentric axial dipole (GAD) hypothesis, which states that adequately sampled rock units that acquired remnant magnetizations over thousands of years will retain a remanence directed toward geographic north with an inclination given by the dipole formula $\tan (\mathrm{I})=2 \tan (\lambda)$, where $\mathrm{I}$ is the paleomagnetic inclination and $\lambda$ is latitude. Assuming a GAD field, a site located in Central Greece (star in Figure 1) should have experienced a time-averaged magnetic inclination of $56.5 \pm 2.5^{\circ}$ during Middle Miocene time [accounting for global plate motion using either the African or European apparent 
polar wander (APW) paths of Torsvik et al., 2008]. This is essentially indistinguishable from their present latitude, and implies that they have been mostly stationary since this time. However, paleomagnetic inclinations reported from rocks of Miocene and younger age in the Aegean region range from 25 to $50^{\circ}$, thus exhibiting a systematic inclination shallowing (Beck and Schermer, 1994). This has led to suggestion that the local time-averaged geomagnetic field was different from the GAD model (Morris and Anderson, 1996; Avigad et al., 1998), that the Aegean region was actually $\sim 500 \mathrm{~km}$ south of its present position in Miocene time (Beck and Schermer, 1994; Beck et al., 2001; Aidona et al., 2008; Kondopoulou et al., 2011), or that the paleomagnetic data exhibit systematic shallow biases (Krijgsman and Tauxe, 2004; Tauxe et al., 2008).

With respect to the latter, small amounts of inclination shallowing can be attributed to a variety of factors. Shallow inclinations in sedimentary rocks can result from processes of grain settling and subsequent compaction flattening, as in the case of the Miocene marine rocks of Crete (Krijgsman and Tauxe, 2004; Tauxe et al., 2008). Small datasets ( $<20$ site mean directions) are statistically biased toward shallow inclinations by up to $\sim 5^{\circ}$ (Krijgsman and Tauxe, 2004), as are rapidlycooled igneous rocks that temporally under sample paleosecular variation. The use of unit vectors instead of total vectors (which require paleointensity data) for calculation of mean directions can result in artificial shallowing of several degrees as a purely mathematical effect (Creer, 1983).

However, these mechanisms are insufficient to account for the large amount of inclination shallowing observed at several critical localities. In particular, shallow inclinations reported from Early to Middle Miocene lacustrine and volcanic rocks of the Kymi-Aliveri basin on the island of Evia and Middle Miocene plutons and dykes on the nearby islands of Tinos, Mykonos, and Naxos (Figure 1) have been considered as strong evidence for a systematic Aegean shallow inclination bias (Morris and Anderson, 1996; Avigad et al., 1998). These rocks were deposited or emplaced during development of the North Cycladic Detachment System, which consists of a set of closely related, northeastward-dipping low-angle normal faults that accommodated exhumation of deepseated metamorphic rocks to Earth's surface (Lister et al., 1984; Jolivet et al., 2010).

Because paleomagnetism of pre-, syn-, and post-detachment igneous rocks can uniquely constrain aspects of the kinematics of late-stage exhumation and subsequent regional block rotation, resolution of the shallow inclination problem in this region is of critical importance. Here, we address this problem by re-examining the paleomagnetic data from the Kymi-Aliveri basin and the islands of Tinos, Mykonos, and Naxos.
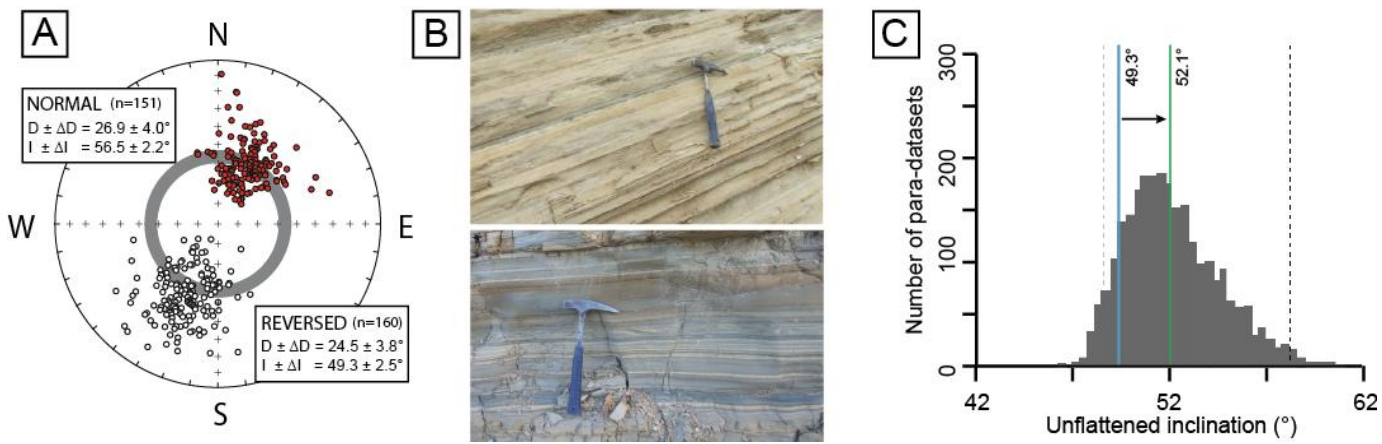

Figure 2. A) Tilt-corrected specimen-level characteristic remanence directions from the Kymi Formation. Gray band shows the expected magnetic inclination of $56.5 \pm 2.5^{\circ}$ at the time of deposition. B) Field photographs of silt-poor (top) and silt-rich (bottom) facies of the Kymi Formation. C) Correction of reversed-polarity mean inclination from $49.3^{\circ}$ to $52.1^{\circ}$ by the elongation-inclination method (Krijgsman and Tauxe, 2004) assuming sedimentary compaction as the origin of the anomalously shallow remanence. Dashed lines bracket the $\mathbf{9 5 \%}$ confidence interval for the corrected inclination. 


\section{The Kymi-Aliveri Basin}

The Kymi-Aliveri basin consists of a basal sequence of Early to Middle Miocene lacustrine marls, siltstones, and sandstones (Figure 2) that pass upward into and are locally unconformably overlain by Middle Miocene fluvial/alluvial conglomerates (Bradley et al., 2013). The Middle Miocene Oxylithos dacites were intruded into (and perhaps locally erupted onto; Pe-Piper and Piper, 1994) this sequence. The Kymi-Aliveri basin developed synchronously with the main period of exhumation of rocks to shallow crustal levels along low-angle normal faults in the adjacent AtticCycladic Complex, and is bounded to the southeast by the South Evia-North Attica Fault (Fig. 1) (Xypolias et al., 2003; Papanikolaou and Royden, 2007; Papanikolaou and Papanikolaou, 2007 Jolivet et al., 2010; Soukis and Stockli, 2012).

The close association between a thick succession of well-exposed sediments and coeval volcanics makes the Kymi-Aliveri basin an attractive location for paleomagnetic sampling (Kissel et al., 1986; Morris, 1995; Bradley et al., 2013). Pioneering paleomagnetic studies in the Kymi-Aliveri basin yielded consistent paleomagnetic directions from both the Kymi Formation and the Oxylithos volcanics (Kissel et al., 1986; Morris, 1995). All sites in these studies exhibited mean inclinations of $\sim 40-45^{\circ}$ after tilt correction, well below the expected inclination of $56.5^{\circ}$. Notably, these studies sampled only reversed-polarity intervals of the Kymi Formation (Kissel et al., 1986; Morris, 1995). In order to test whether the reported shallow inclinations were due in part to shallow biases of reversed-polarity directions, we intensively sampled $\sim 750 \mathrm{~m}$ of stratigraphic section of the Kymi Formation. The samples were analysed in the MIT Paleomagnetism Laboratory, with details of the analytical procedures, demagnetization characteristics, quality criteria, and stability tests presented in Bradley et al. (2013).
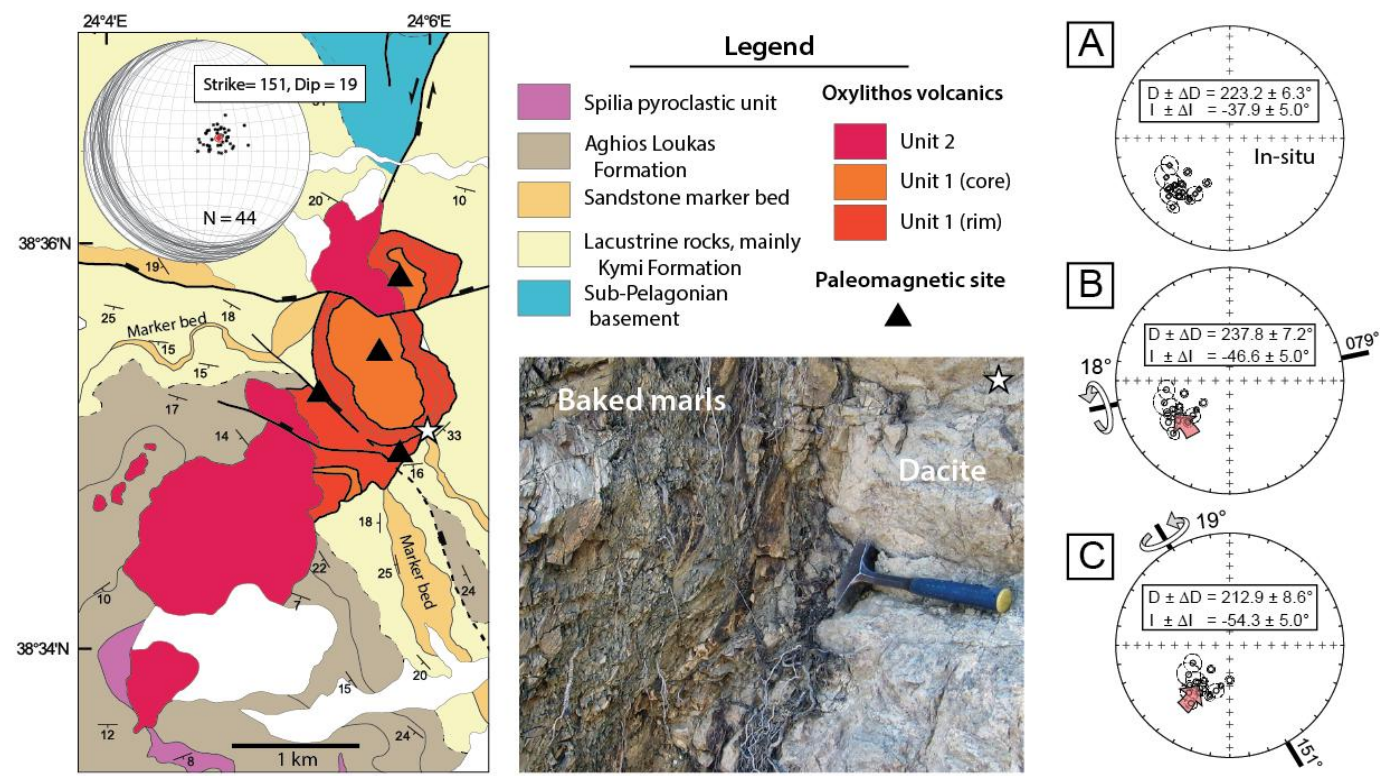

Figure 3. Paleomagnetism of the Oxylithos dacites. White star on map indicates location of photograph showing intrusive contact between dacite and lacustrine marls. A) In-situ paleomagnetic data from Unit 1 (Kissel et al., 1986; Morris, 1995; Bradley et al., 2013). B)

Tilt correction proposed by Kissel et al. (1986) and Morris (1995). C) Tilt correction using the orientation of the youngest beds intruded by the dacites (stereonet at upper left of figure).

Out of 311 accepted characteristic remanence directions, the reversed-polarity directions are on average $7.2^{\circ}$ shallower than those with normal polarity (Figure 2A). In the Kymi-Aliveri basin, the 
normal-polarity intervals are characterized by carbonate-rich marls and lacustrine limestones, while the reversed-polarity intervals exhibited higher silt content (Figure 2B), suggesting that enhanced compaction of silty beds could explain the shallow bias of the reversed-polarity dataset. Application of the elongation-inclination method (Krijgsman and Tauxe, 2004; Tauxe et al., 2008) to the reversed-polarity directions yields an elongation-corrected mean inclination of $52.1^{\circ}(+6.0$, 3.5), bracketing the expected Middle Miocene inclination (Figure 2C). Alternatively, the shallow nature and higher dispersion of reversed-polarity specimens may reflect incomplete thermal cleaning of a modern normal-polarity viscous overprint from the reversed-polarity specimens (Parés and van der Voo, 2013). The normal-polarity magnetization of the Kymi Formation therefore appears to be most closely representational of the ambient field direction during deposition. This interpretation is supported by observation of similar effects in large paleomagnetic datasets with depositional paleolatitudes that are independently known from plate reconstructions (Tauxe et al., 2008).

The Oxylithos intrusive dacites yielded highly consistent site-mean directions (Figure 3A) in three separate studies (Kissel et al., 1986; Morris, 1995; Bradley et al., 2013). These dacites do not exhibit bedding or paleohorizontal indicators. Kissel et al. (1986) and Morris (1995) applied a tilt correction to these directions based on the attitude of southward-dipping marls exposed along the nearby Kymi-Platana road. Application of this correction to the combined dataset yields an anomalously shallow mean inclination similar to that of the reversed-polarity data from the Kymi Formation and a large inferred clockwise vertical-axis rotation of $\sim 58^{\circ}$ (Figure $3 \mathrm{~B}$ ). Based on new geological mapping, we instead find that the dacites are intruded into and slightly postdate the lacustrine section, invalidating this tilt correction. We propose an alternative tilt-correction that restores to horizontal the youngest beds intruded by the dacites (Figure 3). Application of this correction to the combined dataset yields a mean inclination of $54.3 \pm 5^{\circ}$ and an inferred clockwise vertical-axis rotation of $32.9 \pm 8.6^{\circ}$, consistent with the magnetization of the slightly older Kymi Formation (Figure 3C). We therefore find no evidence from the sedimentary rocks or volcanics of the Kymi-Aliveri basin for a Middle Miocene Aegean inclination anomaly.

\section{Paleomagnetism of Northwestern Cycladic Igneous Rocks}

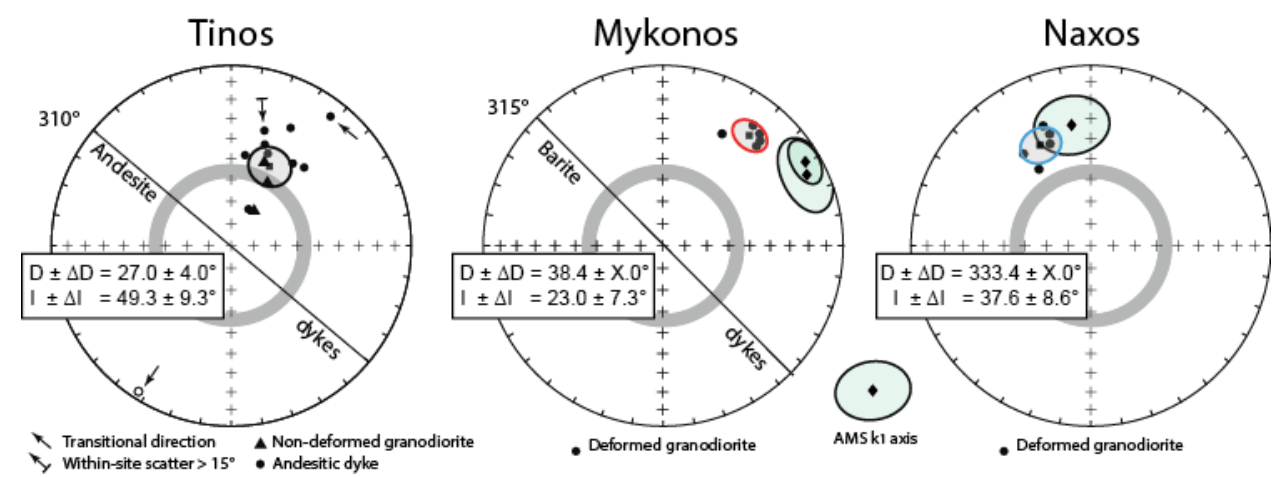

Figure 4. Summary of published paleomagnetic and magnetic fabric data from the islands of Tinos, Mykonos, and Naxos. Data are from Morris and Anderson (1996), Avigad et al. (1998), and Denèle et al. (2012). Gray bands show the expected Middle Miocene inclination.

From 15-10 Ma, a variety of plutons and dykes were intruded into the Attic-Cycladic Complex (Bolhar et al., 2010; Jolivet et al., 2010). On Tinos, a syn-detachment 14.73 \pm 0.22 Ma granodiorite (s.1.) pluton and a set of 11.55 \pm 0.43 Ma post-detachment dacitic dykes are exposed (Avigad et al., 1998; Bolhar and Ring, 2010). On Mykonos and Naxos, 13.4-11 Ma granodiorite (s.1.) plutons are also exposed (Bolhar et al., 2010; Brichau et al., 2008).

Remanent magnetizations for the Tinos pluton and dykes are characterized by final unblocking temperatures of $\sim 580^{\circ} \mathrm{C}$ and little unblocking below $500^{\circ} \mathrm{C}$, indicating that low-Ti titanomagnetite 
dominates the magnetic remanence (Avigad et al., 1998). In contrast, paleomagnetic remanence at Mykonos and Naxos is dominated by a component with low unblocking temperatures $\left(<\sim 350^{\circ} \mathrm{C}\right)$ and a subordinate component with high unblocking temperatures of up to $580^{\circ} \mathrm{C}$, carried by low-Ti titanomagnetite (Morris and Anderson, 1996). The published mean inclinations for Tinos, Mykonos, and Naxos are $41.9 \pm 9.9^{\circ}, 23.0 \pm 7.3^{\circ}$, and $37.6 \pm 8.6^{\circ}$, respectively (Morris and Anderson, 1996; Avigad et al., 1998) (Figure 4). These authors argued that such shallow inclinations, which are statistically distinguishable from the expected Middle Miocene inclination of $56.5 \pm 2.5^{\circ}$, should be interpreted in the context of the $\sim 42^{\circ}$ mean inclination reported for the contemporary rocks of the Kymi-Aliveri basin under the assumption of a regional inclination anomaly. Our revision of the paleomagnetism of the Kymi-Aliveri basin invalidates this correction, exacerbating rather than mitigating the shallow inclination problem in the western Cyclades.

The published mean inclination of $41.9 \pm 9.9^{\circ}$ at Tinos depends strongly on two sites exhibiting nearly equatorial inclinations. These specific sites incorporate only 3 out of 6 (for site T1) and 2 out of 5 (for site T4) specimens (Avigad et al., 1998), the lowest ratios of analyzed to utilized specimens in the dataset. Furthermore, site T1 exhibits a nearly reversed polarity, but its mean direction is not antipodal to the cluster of normal-polarity sites, suggesting that it records a transitional direction. Exclusion of T1 and T4 as well as the site with greatest scatter (T13; Fisher $95 \%$ confidence interval $\alpha 95=19.5^{\circ}$ ) yields a revised mean inclination of $49.3 \pm 9.9^{\circ}$. As the confidence interval for this inclination overlaps with the expected magnetic inclination for a Middle Miocene GAD (Figure 4), inference of an anomalous shallow inclination depends on inclusion of the three lowest-reliability sites, suggesting that the inferred shallow inclination could be an artefact of the small number of analysed samples and sites.
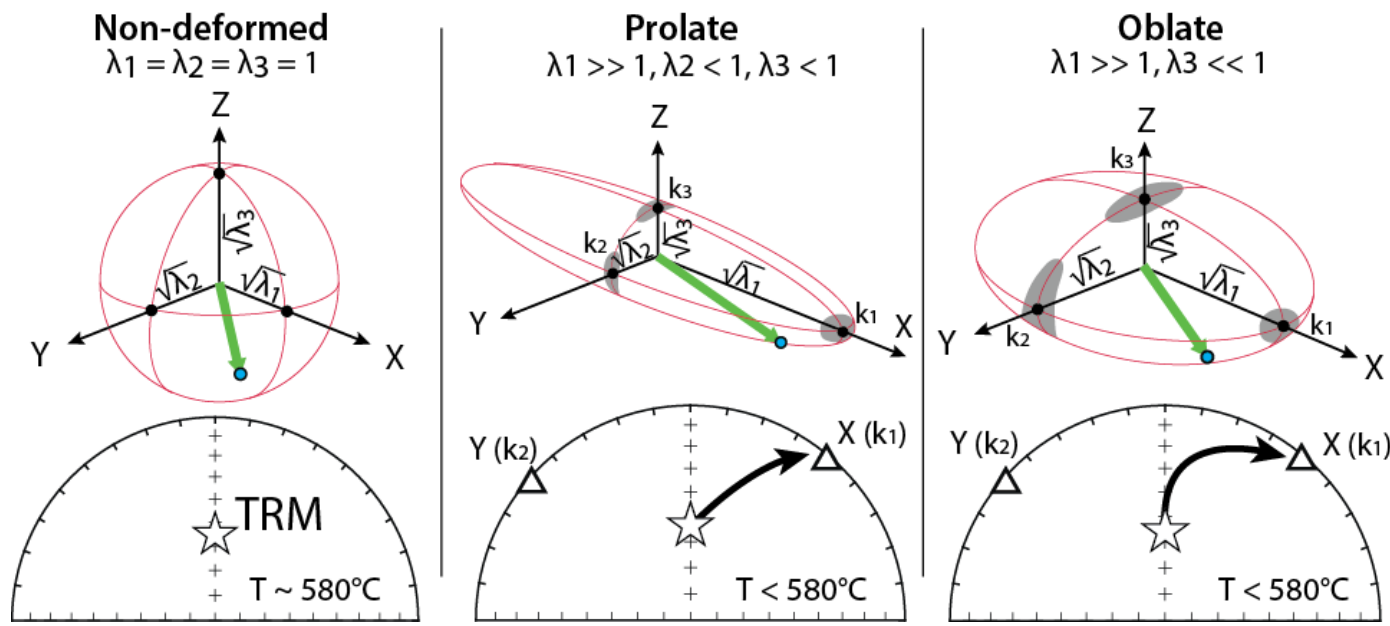

Figure 5. Transposition of a primary thermal remanent magnetization (TRM; open star) acquired during cooling below $580^{\circ} \mathrm{C}$ by oblate or prolate coaxial strain at temperatures of $350-500^{\circ} \mathrm{C}$ (after Borradaile, 1997). Green arrow: paleomagnetic remanence direction.

The simplest way to explain shallow paleomagnetic inclinations within extensional terranes is by back-tilting of fault-bounded blocks. This mechanism requires minimum back-tilting of Tinos, Mykonos and Naxos by $7.2^{\circ}, 33.5^{\circ}$ and $18.9^{\circ}$, respectively. However, the similar strike of vertical andesite dykes on Tinos and barite dykes on Mykonos indicate that there has been little relative vertical-axis rotation or differential tilting between the footwalls of those islands since $\sim 11 \mathrm{Ma}$ (Avigad et al., 1998). The difference in magnetic inclination of $\sim 26.3^{\circ}$ between coeval rocks at Tinos and Mykonos cannot be explained solely by block tilting.

We therefore seek an alternative model for the origin of shallow inclinations at Mykonos and Naxos. All sites at these localities were drilled within rocks exhibiting a pronounced non- 
magmatic foliation and a well-developed mineral lineation. This lineation parallels the principal (k1) axis of the anisotropy of magnetic susceptibility tensor measured at each paleomagnetic drill site (Figure 4; Morris and Anderson, 1996). The tectonic fabrics record crystal-plastic deformation at temperatures down to $\sim 350^{\circ} \mathrm{C}$, well below the $560-580^{\circ} \mathrm{C}$ blocking temperature of low-Ti titanomagnetite (Lee and Lister, 1992). Temperatures of mylonitization of $400-500^{\circ} \mathrm{C}$ have been observed in other metamorphic core complexes where syn-detachment plutonic rocks that are lithologically and structurally comparable to the Tinos and Mykonos plutons (e.g., Singleton and Mosher, 2012). Any primary thermoremanent magnetization acquired by cooling of low-Ti titanomagnetite grains below $580^{\circ} \mathrm{C}$ during initial post-crystallization cooling would therefore have significantly predated the cessation of ductile deformation.

Paleomagnetic remanence vectors carried by robust, elongate magnetic grains can rotate as passive lines under ductile deformation due to grain reorientation (Borradaile, 1997), with the mean remanence vector following an arcuate path toward the intermediate strain axis before converging on the maximum elongation direction (Figure 5A-C). While this effect has not to our knowledge been described in granite mylonites, the basic physical principles are closely analogous to wellstudied examples (Borradaile, 1997). The magnitude and sense of angular deflection of a magnetization originally acquired in the expected (GAD) local field direction can therefore be estimated from finite strain measurements, assuming that strain was dominantly coaxial and that the axes of the anisotropy of magnetic susceptibility tensor measured at the paleomagnetic drill sites represent the finite strain axes. This approach requires knowledge of the paleo-north direction independent of the magnetization directions of the Cycladic plutons. Realignment of footwall lineations across the Mid-Cycladic Lineament (Walcott and White, 1998) requires $\sim 50^{\circ}$ of relative vertical-axis rotation between Mykonos and Naxos (Philippon et al., 2011). As the region northwest of the Mid-Cycladic Lineament is known to have rotated by $\sim 25^{\circ}$ clockwise since Middle Pliocene time (Bradley et al., 2013), the region to the southeast, including the island of Naxos, must have rotated counter-clockwise by $\sim 25^{\circ}$.

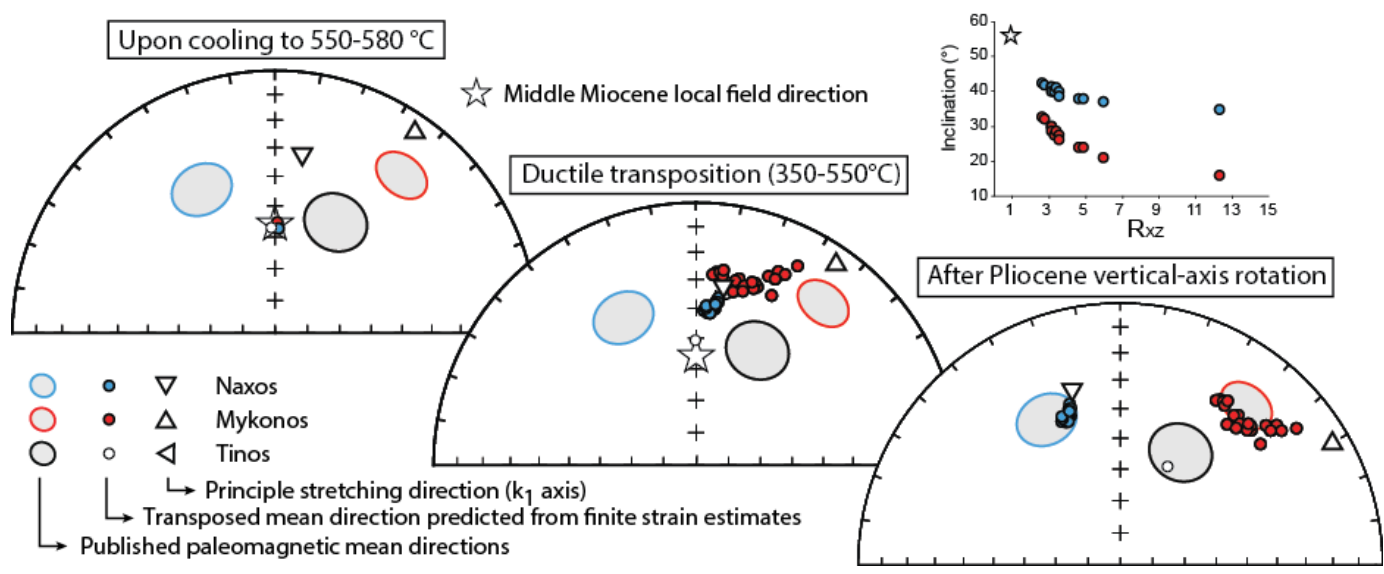

Figure 6. Hypothesized evolution of the paleomagnetic remanence of Tinos, Mykonos, and Naxos, accounting for ductile deflection of a primary thermoremanent magnetization using the strain ellipsoids measured on Naxos (Koukouvelas and Kokkalas, 2003) oriented by the principal axes of the magnetic susceptibility tensors measured at the paleomagnetic drill sites on both Naxos and Mykonos (Morris and Anderson, 1996).

For the case of Naxos, we adopt the 23 finite strain measurements of Koukouvelas and Kokkalas (2003), with the k1 and k3 axes of Morris and Anderson (1996) taken as the maximum and minimum elongation directions, respectively, of the finite strain ellipsoid. The resulting average remanence direction is $\sim 005^{\circ} / 41^{\circ}$ (a flattening of $15.5^{\circ}$ ), which restores to a present-day remanence direction of $340^{\circ} / 41^{\circ}$ after accounting for post-Miocene counter-clockwise rotation of $25^{\circ}$ (Figure 6). Finite strain data are not presently available for the Mykonos pluton. If we assume 
that the style and intensity of strain in the Mykonos pluton is similar to that at Naxos, but with the direction of maximum elongation oriented toward the k1 and k3 axes measured at Mykonos (Morris and Anderson, 1996; Denèle et al., 2011), we predict a deflected remanence direction of $015^{\circ} / 30^{\circ}$ and, after accounting for post-Miocene clockwise rotation of $25^{\circ}$, a present-day remanence direction of $040^{\circ} / 30^{\circ}$ (Figure 6). Because the largest amount of flattening and rotation of the remanence occurs at relatively low strain (strain ratio RXZ $<2$; Figure $5 \mathrm{~F}$ ), the magnitude of the predicted deflection does not depend strongly on the details of the finite strain, so long as a stretching lineation is present and significant flattening has occurred (Figure 6, inset at upper right).

Ductile transposition of magnetizations acquired by cooling below $580^{\circ} \mathrm{C}$ in the expected ambient geomagnetic field can therefore explain the relative magnitude of inclination shallowing observed

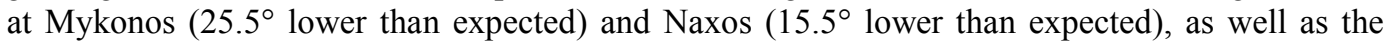
more easterly declination of the remanence at Mykonos compared with Tinos.

However, our proposed model fails to explain strong demagnetization of specimens from Naxos and Mykonos at temperatures $<350-400^{\circ} \mathrm{C}$. If this temperature range represents blocking temperatures, then magnetization must have postdated mylonitization. These magnetizations were originally attributed to monoclinic pyrrhotite, which demagnetizes upon heating to $\sim 320^{\circ} \mathrm{C}$ (Grønvold and Haraldsen, 1952). However, to date no iron sulfides have been petrographically identified within the Mykonos or Naxos plutons. An alternative magnetic carrier is cation-deficient titanomaghemite, which undergoes inversion to hematite upon heating to $\sim 350^{\circ} \mathrm{C}$, resulting in demagnetization in the same temperature range as pyrrhotite-bearing rocks (O'Reilly, 1983). Lowtemperature $\left(<350^{\circ} \mathrm{C}\right)$ oxidation of fine-grained, acicular titanomagnetite can result in the production of intimately overgrown secondary titanomaghemite bearing a stable chemical remanent magnetization parallel to that of the original titanomagnetite grain (Heider and Dunlop, 1987). We suggest that after cooling through the brittle/ductile transition at temperatures of $\sim 300$ $350^{\circ} \mathrm{C}$, low-temperature oxidative alteration led to growth of fine-grained titanomaghemite that acquired a remanence parallel to the already rotated high-temperature paleomagnetic remanence, which is now the primary paleomagnetic signal. In contrast, the dykes and plutonic rocks of Tinos, where sampled, were not penetratively strained or altered and therefore preserve both their igneous magnetic mineralogy and primary remanence direction.

\section{Conclusions}

Early to Middle Miocene sedimentary and volcanic rocks exposed in the Kymi-Aliveri basin and on the island of Tinos preserve paleomagnetic inclinations that are consistent with emplacement near their present-day latitude. Standard interpretation of the remanence directions at Mykonos and Naxos requires large fault-block tilts incompatible with independent structural constraints. We suggest an alternative interpretation of ductile transposition of a primary thermal remanent magnetization carried by low-Ti titanomagnetite followed by low-temperature maghemitization. This model can explain the progressive flattening and rotation toward the mylonitic stretching direction of paleomagnetic remanences at Mykonos and Naxos. Based on this new interpretation, the paleomagnetic data from the Central Greece and the western Cyclades do not require anomalous field geometries, significant northward drift of Aegean, or back-tilting of the low-angle normal faults of the North Cycladic Detachment System (Avigad et al., 1998). Our proposed model can and should be directly tested by coupled microstructural, rock magnetic, and paleomagnetic studies of deformed footwall plutons, as exemplified by the recent study of Zananiri et al. (2013) of the deformed Symvolon and Vrondou plutons of northern Greece.

\section{Acknowledgments}

This work was funded by NSF Continental Dynamics grant EAR-0409373. We thank J.S. Berdahl, A. Piasecki, and A. Hosa for their contributions to field sampling and laboratory analysis. We 
thank B.C. Burchfiel, and D. Papanikolaou for their contributions to our understanding of Aegean geology.

\section{References}

Aidona E., Kondopoulou D., Scholger R., Georgakopoulos A. and Vafeidis A. 2008. Palaeomagnetic investigations of sediments cores from Axios zone (N. Greece): implications of low inclinations in the Aegean, EEarth, 3(1), 7-18.

Avigad D., Baer G. and Heimann A. 1998. Block rotations and continental extension in the central Aegean Sea: palaeomagnetic and structural evidence from Tinos and Mykonos (Cyclades, Greece), Earth and Planetary Science Letters, 157(1), 23-40.

Beck M. and Schermer S. 1994 "Aegean paleomagnetic inclination anomalies. Is there a tectonic explanation?, Tectonophysics, 231(4), 281-292.

Beck M. E., Burmester R. F., Kondopoulou D. P. and Atzemoglou A. 2001. The palaeomagnetism of Lesbos, NE Aegean, and the eastern Mediterranean inclination anomaly, Geophysical Journal International, 145(1), 233-245.

Bolhar R., Ring U. and Allen C. M. 2010. An integrated zircon geochronological and geochemical investigation into the Miocene plutonic evolution of the Cyclades, Aegean Sea, Greece: Part 1: Geochronology, Contributions to Mineralogy and Petrology, 160(5), 719-742.

Borradaile G. J. 1997. Deformation and paleomagnetism, Surveys in geophysics, 18(4), 405-436.

Bradley K.E., Vassilakis, E., Hosa, A. and Weiss B.P. 2013. Segmentation of the Hellenides recorded by Pliocene initiation of clockwise block rotation in Central Greece, Earth and Planetary Science Letters, 362, 6-19.

Brichau S., Ring U., Carter A., Bolhar R., Monié P., Stockli D. and Brunel M. 2008. Timing, slip rate, displacement and cooling history of the Mykonos detachment footwall, Cyclades, Greece, and implications for the opening of the Aegean Sea basin, Journal of the Geological Society, 165(1), 263-277.

Creer K. 1983. Computer synthesis of geomagnetic palaeosecular variations, Nature, 304, 695 699.

Denèle Y., Lecomte E., Jolivet L., Lacombe O., Labrousse L., Huet B. and Le Pourhiet L. 2011. Granite intrusion in a metamorphic core complex: The example of the Mykonos laccolith (Cyclades, Greece), Tectonophysics, 501(1), 52-70.

Grønvold F. and Haraldsen H. 1952. On the phase relations of synthetic and natural pyrrhotites, Acta Chem. Scand, 6, 1452-1469.

Heider F. and Dunlop D. J. 1987. Two types of chemical remanent magnetization during the oxidation of magnetite, Physics of the earth and planetary interiors, 46(1), 24-45.

Jolivet L., Lecomte E., Huet B., Denèle Y., Lacombe, O., Labrousse, L. and Mehl C. 2010. The north cycladic detachment system, Earth and Planetary Science Letters, 289(1), 87-104.

Kissel C., Laj C. and Mazaud A. 1986. First paleomagnetic results from Neocene Formations in Evia, Skyros and the Volos Region and the deformation of Central Aegea, Geophysical Research Letters, 13(13), 1446-1449.

Kissel C. and Laj C. 1988. The Tertiary geodynamical evolution of the Aegean arc: a paleomagnetic reconstruction, Tectonophysics, 146(1), 183-201.

Kondopoulou D., Sen S., Aidona E., Van Hinsbergen D. J. J. and Koufos G. 2011. Rotation history of Chios island, Greece since the Middle Miocene, Journal of Geodynamics, 51(5), 327-338.

Koukouvelas I. K. and Kokkalas S. 2003. Emplacement of the Miocene west Naxos pluton (Aegean Sea, Greece): a structural study. Geological Magazine, 140(1), 45-61.

Krijgsman W. and Tauxe L. 2004. Shallow bias in Mediterranean paleomagnetic directions caused by inclination error, Earth and Planetary Science Letters, 222(2), 685-695.

Lee J. and Lister G. S. 1992. Late Miocene ductile extension and detachment faulting, Mykonos, Greece, Geology, 20(2), 121-124. 
Lister G. S., Banga G. and Feenstra A. 1984. Metamorphic core complexes of Cordilleran type in the Cyclades, Aegean Sea, Greece, Geology, 12(4), 221-225.

Morris A. 1995. Rotational deformation during Palaeogene thrusting and basin closure in eastern central Greece: palaeomagnetic evidence from Mesozoic carbonates, Geophysical Journal International, 121, 827-847.

Morris A. and Anderson M. 1996. First palaeomagnetic results from the Cycladic Massif, Greece, and their implications for Miocene extension directions and tectonic models in the Aegean, Earth and Planetary Science Letters, 142(3), 397-408.

O'Reilly W. 1983. The identification of titanomaghemites: model mechanisms for the maghemitization and inversion processes and their magnetic consequences, Physics of the Earth and Planetary Interiors, 31(1), 65-76.

Papanikolaou D. and Papanikolaou I. 2007. Geological, geomorphological and tectonic structure of NE Attica and seismic hazard implications for the northern edge of Athens plain, Bulletin of the Geological Society of Greece, 40, 425-438.

Papanikolaou D. J. and Royden L. H. 2007. Disruption of the Hellenic arc: Late Miocene extensional detachment faults and steep Pliocene-Quaternary normal faults-Or what happened at Corinth?, Tectonics, 26(5), TC5003.

Parés J. M. and Van der Voo R. 2013. Non-antipodal directions in magnetostratigraphy: an overprint bias?, Geophysical Journal International, 192(1), 75-81.

Pe-Piper G. and Piper D. J. 1994. Miocene magnesian andesites and dacites, Evia, Greece: adakites associated with subducting slab detachment and extension, Lithos, 31(3), 125-140.

Philippon M., Brun J. P. and Gueydan F. 2011. Deciphering subduction from exhumation in the segmented Cycladic Blueschist Unit (Central Aegean, Greece), Tectonophysics, 524-525, 116-134.

Singleton J. S. and Mosher S. 2012. Mylonitization in the lower plate of the Buckskin-Rawhide detachment fault, west-central Arizona: Implications for the geometric evolution of metamorphic core complexes, Journal of Structural Geology, 39, 180-198.

Soukis K., and Stockli D. F. 2012. Structural And Thermochronometric Evidence For Multi-Stage Exhumation Of Southern Syros, Cycladic Islands, Greece, Tectonophysics, 595-596, 148164.

Tauxe L., Kodama K. P. and Kent D. V. 2008. Testing corrections for paleomagnetic inclination error in sedimentary rocks: a comparative approach, Physics of the Earth and Planetary Interiors, 169(1), 152-165.

Torsvik T. H., Müller R. D., Van der Voo R., Steinberger B. and Gaina C. 2008. Global plate motion frames: toward a unified model, Reviews of Geophysics, 46(3), RG3004.

Van Hinsbergen D. J. J., Langereis C. G. and Meulenkamp J. E. 2005. Revision of the timing, magnitude and distribution of Neogene rotations in the western Aegean region, Tectonophysics, 396(1), 1-34.

Walcott C. R. and White S. H. 1998. Constraints on the kinematics of post-orogenic extension imposed by stretching lineations in the Aegean region, Tectonophysics, 298(1), 155-175.

Xypolias P., Kokkalas S. and Skourlis K. 2003. Upward extrusion and subsequent transpression as a possible mechanism for the exhumation of HP/LT rocks in Evia Island (Aegean Sea, Greece), Journal of Geodynamics, 35(3), 303-332.

Zananiri I., Kondopoulou D., Dimitriadis S. and Kilias A. 2013. Insights into the geotectonic evolution of the southern Rhodope as inferred from a combined AMS, microtextural and paleomagnetic study of the Tertiary Symvolon and Vrondou plutons, Tectonophysics, 595596, 106-124. 